\title{
Notagildi ígræddra taktnema við mat á óútskýrðu yfirliði og hjartsláttarópægindum
}

Ingibjörg Kristjánsdóttir læknir, Guðrún Reimarsdóttir lífeindafræðingur, Davío O. Arnar læknir

\section{ÁGRIP}

Tilgangur: Yfirlið eru algeng og getur reynst erfitt að greina orsök peirra. Markmið rannsóknarinnar var að kanna frumárangur af notkun ígræddra taktnema við mat á orsökum óútskýrðra yfirliða og hjartsláttarbæginda. Efniviður/aðferðir: Rannsóknin var afturskyggn og náđi til 18 sjúklinga sem fengið hafa ígræddan taktnema hérlendis. Af pessum 18 eru 5 enn með tækið ígrætt og ekki komin endanleg niðurstaða af vöktun hjartatakts hjá peim. Pessir sjúklingar höfðu farið í gegnum ítarlegar rannsóknir án pess að skýring hefði fundist og var pví um valinn hóp einstaklinga að ræða.

Niðurstöður: Af peim 13 sjúklingum par sem vöktun hjartatakts var lokið var meðalaldur $65 \pm 20$ ára. Í öllum tilfellum nema einu var taktnemi hafður inni par til skýring á einkennum var fundin eða rafhlaða kláraðist, meðaltími i sjúklingi var 20ะ13 mánuðir. Óútskýrt yfirlið var algengasta ábendingin, eða hjá 11 sjúklingum, en hjá hinum tveimur var tækið sett inn vegna óútskýrðra hjartsláttarópæginda. Hjá fjórum fannst merki um sjúkan sinushnút, hjá premur ofansleglahrađtaktur og í einu tilfelli sleglahraðtaktur. Hjá premur sjúklingum var hægt að útiloka truflun á hjartatakti sem orsök einkenna bar sem reglulegur sinustaktur sást samfara dæmigerðum einkennum. Tveir sjúklingar fengu engin einkenni á meðan beir voru með taktnemann. Af beim 5 sjúklingum sem eru enn með taktnemann inni og vöktun enn í gangi var ábendingin yfirlið hjá premur en hjá tveimur er tækið notað til að fylgjast með árangri meðferðar á hjartsláttartruflunum.

Ályktanir: Pessar frumniðurstöður sýna fram á skýran ávinning af notkun ígrædds taktnema við rannsóknir á óútskýrðum yfirliðum og hjartsláttaróbægindum.
Lyflækningasvið Landspítala Hringbraut.

Fyrirspurnir: Davíð O. Arnar

davidar@landspitali.is 1. janúar 2012, sampykkt til birtingar 7. ágúst 2012.

Engin hagsmunatengs। gefin upp.

\section{Inngangur}

Yfirlið er nokkuð algengt einkenni og lætur nærri að um $1 \%$ koma á bráđamóttökur séu vegna pessa vandamáls. ${ }^{1,2}$ Oft eru orsakir yfirliða ekki af alvarlegum toga en stöku sinnum geta pær pó verið lífshættulegar, sér í lagi ef vandamálið tengist undirliggjandi hjartasjúkdómi. ${ }^{3,4}$ Undir slíkum kringumstæðum geta hættulegar hjartsláttartruflanir verið orsakavaldur yfirliðs. Раð getur hins vegar verið erfitt að greina pessar hjartsláttartruflanir. Langur tími getur liðið á milli einkenna og hjartataktur er í mörgum tilfellum algerlega eðlilegur inni á milli. Greining á meinalífeðlisfræði yfirliða getur par af leiðandi verið vandasöm og talið er að í allt að fimmtungi tilfella sé orsökin óútskýrð prátt fyrir ítarlegar rannsóknir. ${ }^{5,6}$

Ef grunur er um hjartsláttartruflun sem orsök yfirliðs er ábending fyrir frekari rannsóknum. Pá er gjarnan byrjað á nánari athugun á hjartatakti með 24 klukkustunda Holter-sírita. Slíka rannsókn er auðvelt að framkvæma og aðgengi að peim gott. Næsta skref, ef 24 klukkustunda Holter gefur ekki niðurstöðu, er oft svokallaður 14 daga hjartsláttarsíriti (event recorder). Slíkar rannsóknir skila pó takmörkuðum árangri ef mjög langt er á milli einkenna.

Ígræddur taktnemi (implantable loop recorder) er athyglisverð og tiltölulega nýleg rannsóknaraðferð til vöktunar á hjartatakti. ${ }^{7}$ Taktneminn er á stærð við USB-minniskubb (mynd 1) og er komið fyrir undir húð miðlægt framan á bringu með einfaldri aðgerð. Tækið vaktar hjartsláttinn stöðugt og geymir frávik frá eðlilegum hjartatakti í minni. Skilmerki um pau frávik

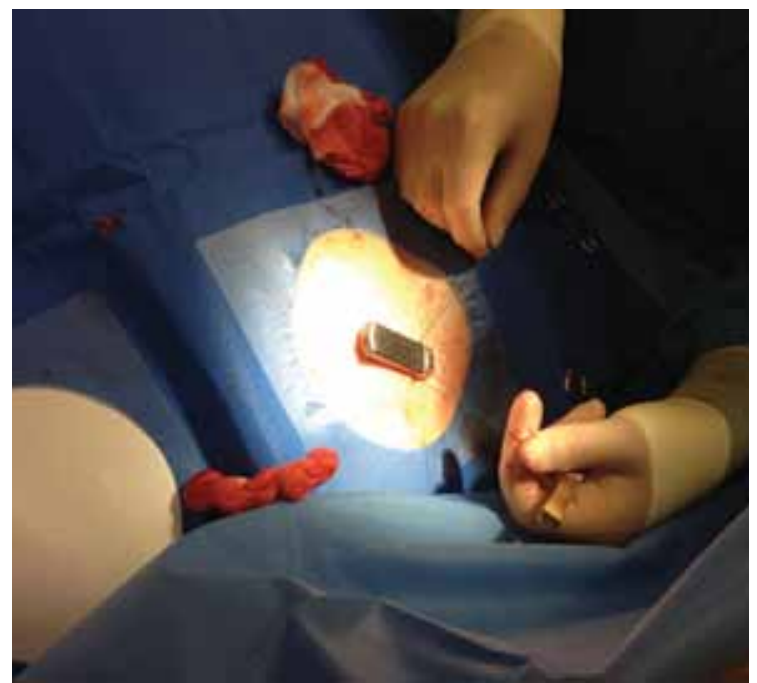

Mynd 1. Ígræddur taktnemi er á stærð við USB-minniskubb.

sem geyma á eru forritað í tækið í hverju tilfelli fyrir sig. Hverju fráviki fylgir einnar leiðslu hjartalínurit sem unnt er að skoða á skjá og prenta út. Mögulegt er að sækja pessar upplýsingar hvenær sem er með sérstökum tölvubúnaði (implantable electronic device programmer), líkt og gert er pegar fylgst er með gangráoum og bjargráðum. Pessi tækni er pví mikilvæg viðbót við rannsóknir hjá einstaklingum með óútskýrð yfirlið og hjartsláttarópægindi.

Ígræddir taktnemar hafa verið í notkun hérlendis um nokkurra ára skeið. Markmið pessarar samantektar var að kanna ábendingar og frumávinning af notkun peirra á Landspítala. 


\section{Efniviður og aðferðir}

Um var að ræða afturskyggna rannsókn á notkun ígræddra taktnema á Landspítala frá 2001 til 2012. Gögnum pessara sjúklinga er haldið til haga á göngudeild gangráða og bjargráða. Peir komu að jafnaði til eftirlits par á eins til tveggja mánaða fresti eftir að taktneminn hafði verið settur inn og par til hann var fjarlægður. Í hverri heimsókn var lesið af minni tækjanna og hjartalínurit peirra frávika sem höfðu verið geymd í minni tækisins voru skoðuð. Kannaðar voru ábendingar fyrir ígræddum taktnema í hverju tilfelli fyrir sig og til hvaða niðurstöðu eða ákvörðunar pessi vöktun á hjartslættinum leiddi.

Allir ígræddir taktnemar sem notaðir voru á pessu tímabili voru af tegundinni Reveal frá Medtronic og var komið fyrir undir húð framan á bringu í staðdeyfingu. Í hverju tilfelli var sérstaklega forritað hvaða frávik ætti að geyma í minni tækisins. Sem dæmi um algeng frávik voru eyður í hjartslætti yfir prjár sekúndur, tilvik hægatakts undir 40 slög á mínútu og hraðtaktur yfir 150 slög á mínútu. Í öllum tilfellum fengu sjúklingar sérstaka fjarstýringu sem peir gátu notað til að virkja geymslu upplýsinga í minni taktnemans svo peir gætu virkjað minnið kæmu einkenni fram. Var petta gert par sem geymsluminnið virkjaðist ekki sjálfkrafa ef einkenni voru ekki vegna hjartsláttarfrávika og pví var hægt að útiloka hjartsláttarfrávik sem ástæðu einkenna ef engar takttruflanir sáust á einkennatímum. Hægt er að forrita hversu lengi hjartarit voru geymd ef sjúklingurinn virkjaði geymsluminni með fjarstýringunni.

Lýsandi tölfræði var notuð við greiningu gagnanna, við skoðun á megindlegum breytum eins og aldri var reiknað meðaltal og staðalfrávik en fyrir eigindlegar breytur var reiknað magn og prósenta.

Persónuvernd og Vísindasiðanefnd Landspítala veittu leyfi til pessarar könnunar.

\section{Niðurstöður}

Á rannsóknartímabilinu fengu 18 einstaklingar ígræddan taktnema á Landspítala. Fimm peirra hafa tækið enn og par af leiðandi er vöktun hjartatakts hjá peim ekki lokið. Sú leið hefur verið farin á Landspítala að takmarka notkun tækjanna við pá sem pegar hafa verið skoðaðir með ítarlegum rannsóknum en skýring á einkennum ekki fundist. Pví var um að ræða mjög valinn hóp sjúklinga sem fékk ígræddan taktnema.

Af peim 13 sjúklingum par sem notkun tækjanna var lokið voru 6 (46\%) karlmenn og 7 (54\%) konur og var meðalaldur $65 \pm 20$ ára, sá yngsti var 31 árs og elsti sjúklingurinn 90 ára. Í langflestum tilfellum, eða 11 (85\%), var oútskýrt yfirlið ábending fyrir taktnemanum, í hinum tveimur (15\%) tilfellum voru oútskýrð hjartsláttarópægindi ábendingin.

Mjög mismunandi var hvað taktneminn var hafður lengi inni, en í velflestum tilfellum var hann fjarlægður eftir að skýring á einkennunum fannst. Að meðaltali voru pessir 13 einstaklingar með tækið í 20ะ13 mánuði, styst í tvo mánuði og lengst í 41 mánuð. Hjá fjórum sjúklingum (31\%) fannst merki um sjúkan sinushnút (mynd 2), hjá premur fannst ofansleglahraðtaktur (23\%) og í einu tifelli (8\%) sleglahraðtaktur. Vissulega getur verið vandasamt að greina sleglahraðtakt með einungis einnar leiðslu riti en hins vegar var um að ræða einstakling með endurtekin yfirlið og

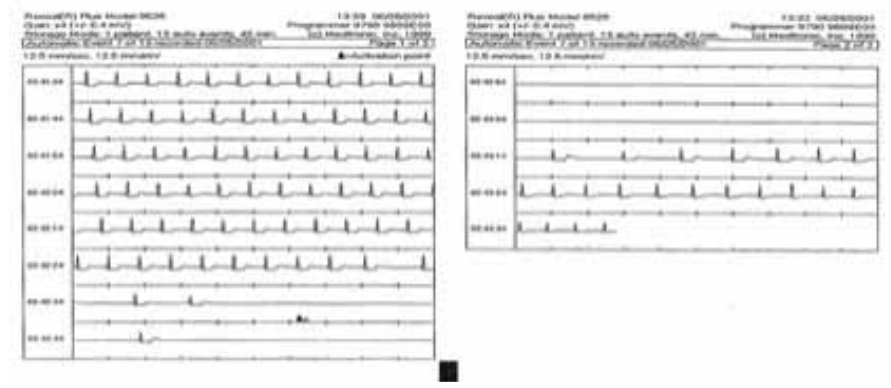

Mynd 2. Útprentun hjartalínurits úr ígræddum taktnema. Myndin sýnir langa eyðu i hjartslætti hjá sjúklingi með endurtekin yfirlið. Hann var meðhöndlaður með gangrád með góðum árangri.

hraðtakt með gleiðum QRS-samstæðum á sama tíma og yfirlið. Sleglahraðtaktur pótti pví líklegasta greiningin. Hjá premur (23\%) komu fram dæmigerð einkenni án pess að takttruflun greindist á sama tíma og var pví mögulegt að útiloka slíkt sem orsök einkenna. Tveir $(15 \%)$ fengu engin einkenni á meðan peir voru með taktnemann.

Af peim 5 sem hafa ígræddan taktnema og eru enn vaktaðir, var ábendingin yfirlið hjá premur og hjá tveimur sjúklingum er tækið notað til að fylgjast með árangri meðferðar á hjartsláttartruflunum.

Ekki voru beinir fylgikvillar af meðferðinni. Einn sjúklingur fékk pó húðsýkingu umhverfis tækið eftir sjóböð erlendis nokkrum mánuðum eftir ísetningu.

\section{Umræða}

Niðurstöður pessarar könnunar á ávinningi notkunar ígræddra taktnema hérlendis sýna að í velflestum tilfellum skilaði vöktun hjartsláttar niðurstöðu sem fól í sér ýmist greiningu eða útilokun á takttruflunum sem orsök einkenna sjúklings. Enda pótt aðeins sé um að ræða tiltölulega fá tilfelli styðja pessar niðurstöður pá nálgun að nota ígrædda taktnema í völdum tilfellum par sem erfitt hefur reynst að greina orsök yfirliða eða hjartsláttaópæginda með einfaldari rannsóknaraðferðum.

Sem fyrr segir geta rannsóknir á orsökum einkenna eins og yfirliða og hjartsláttarópæginda á köflum verið erfiðar, tímafrekar og kostnaðarsamar. Aðeins parf einfalda skurðaðgerð í staðdeyfingu til að setja inn ígræddan taktnema og í nýjustu útgáfu tækisins er rafhlaða sem dugir í allt að 36 mánuði. Tækið tekur upp öll fyrirfram skilgreind frávik frá eðlilegum hjartslætti og einnig getur sjúklingur virkjað geymsluminni tækisins með sérstakri fjarstýringu. Раð er mjög mikilvægt til að tryggja geymslu hjartalínurits á sama tíma og einkenni koma fram pannig að hægt sé að meta pau í samhengi. Pað er mjög mikilvægt að geta tengt takttruflanir við einkenni pví annars getur verið viss vafi um klíníska pýðingu peirra.

Á móti kemur að ígræddur taktnemi kostar um 400.000 krónur og er einnota, sem pýðir að ekki er hægt að endurnýta tæki fyrir annan sjúkling pó svo að pað hafi sannað gagnsemi sína og nóg sé eftir af rafhlöðunni. Petta er pví talsvert dýrara úrræði en aðrar hefðbundnari leiðir til hjartsláttarsíritunar og er pví mikilvægt að okkar mati að reynt sé að rannsaka sjúklinga með einfaldari aðferðum áður en farið er að huga að notkun ígrædds taktnema. 
Nýleg kostnaðargreining á notkun ígrædds taktnema hjá peim sem hafa endurtekin oútskýrð yfirlið eða grun um að yfirlið geti verið af völdum hjartsláttartruflana styður pessa nálgun. ${ }^{7}$

Í vissum tilfellum hefur verið erfitt að greina milli takttruflana frá efri og neðri hólfum hjartans með pessari tækni. Sömuleiðis geta truflanir í línuriti sem og yfirskynjun á T-bylgjum jafnframt torveldað úrlestur á hjartaritinu. Geymsluminnið er takmarkað en auðvelt er að tæma pað við úrlestur á tækinu og endurnýta. Ekki líkar öllum sjúklingum jafn vel að hafa tækið undir húð á bringunni, en pó pað sé tiltölulega fyrirferðarlítið getur pað verið áberandi hjá grönnu fólki.

Pessi tækni hefur verið nokkuð rannsökuð erlendis og hefur ávinningur af notkun tækjanna hjá sjúklingum með óútskýrð yfirlið verið svipaður og reynsla okkar hérlendis. Í einni rannsókn, par sem val á sjúklingum sem fengu ígræddan taktnema var takmarkað við pá sem höfðu undirgengist ítarlegar rannsóknir vegna óútskýrðs yfirliðs, leiddi notkun hans til ákveðinnar niðurstöðu í 88\% tilfella. ${ }^{8}$ Samantekt nokkurra rannsókna, með samtals 247 sjúklingum, sýndi að af peim sem fengu yfirlið meðan peir voru með tækið voru 52\% með hægatakt, 11\% hraðtakt og 37\% enga takttruflun á meðan á einkennum stóð. ${ }^{9}$ Nýlega voru birtar niðurstöður stærstu rannsóknar sem til pessa hefur verið gerð á notagildi ígrædds taktnema, PICTURE-rannsókninni. ${ }^{10}$ Pessi rannsókn tók til yfir 500 sjúklinga í 10 Evrópulöndum og Ísrael en pessir sjúklingar voru með oútskýrð yfirlið og höfðu leitað til margra sérfræðinga, oftast hjarta- og taugalækna, og farið í gegnum margar rannsóknir (á bilinu 9-20) áour en til notkunar á ígræddum taktnema kom. Í langflestum tilfellum leiddi taktneminn til greiningar á orsökum einkenna eða í 78\% tilfella. Мeð hliðsjón af hve miklum tíma, fjármagni og vinnu hafði verið varið í rannsóknir áđur en ígræddur taktnemi var settur inn, leiddu rannsakendur hugann að pví hvort rétt væri að mæla með pví að nota tækið fyrr í rannsóknarferlinu en nú er gert.

Evrópusamtök hjartalækna gáfu út klínískar leiðbeiningar fyrir rannsóknir á yfirliði árið 2009 og er í peim sérstaklega komið inn á notkun ígræddra taktnema. ${ }^{11}$ Par segir að íhuga eigi notkun ígrædds taktnema hjá peim sem hafa endurtekin yfirlið án pess að skýring hafi fengist prátt fyrir ítarlegar rannsóknir, sem er ekki ósvipað og hefur tíðkast hérlendis fram til pessa. Pá er einnig tekið fram að hjá hópi sjúklinga sem fá yfirlið en eru taldir vera í hárri áhættu fyrir skyndidauða ætti að íhuga notkun ígrædds taktnema snemma í rannsóknarferlinu. Til pessa hóps teljast meðal annars peir sem fengu yfirlið við áreynslu eða liggjandi, höfðu hjartsláttarópægindi við yfirliðið, voru með fjölskyldusögu um skyndidauða eða verulega óeðlilegt 12 leiðslu hjartalínurit.

Rannsóknir hafa hins vegar sýnt fram á ákveðið misræmi milli notkunar og ábendinga fyrir notkun á ígræddum taktnema. ${ }^{12}$ prátt fyrir áðurnefndar klínískar leiðbeiningar frá Evrópsku hjartalæknasamtökunum um notkun á ígræddum taktnema við rannsóknir á óútskýrðu yfirliði virðist sjaldnar til hans gripið en ætti að gera. Mögulegar skýringar á pessu voru taldar vera meðal annars hár kostnaður við ígræddan taktnema og visst umfang við eftirlit pessara sjúklinga.

Megintakmörkun pessarar könnunar er fáir sjúklingar en eigi að síður teljum við að hún gefi ákveðna vísbendingu um gagnsemi notkunar pessara tækja hérlendis pó víðtækari ályktanir verði tæpast dregnar. Okkar niðurstöður eru pó að mörgu leyti samhljóða stærri erlendum rannsóknum.

Nýlega hafa ábendingar fyrir ígræddum taktnema verið víkkaðar. ${ }^{11}$ Pannig geta pessi tæki verið gagnleg við að fylgjast með árangri meðferða, til dæmis brennsluaðgerða eða jafnvel lyfjameðferða, en við höfum nýlega notað ígræddan taktnema hjá tveimur sjúklingum í pessum tilgangi hérlendis. Einnig hefur borið á vaxandi notkun pessara tækja hjá sjúklingum með köst sem gætu verið með flogaveiki en sem ekki hafa svarað lyfjameðferð og sömuleiðis hjá sjúklingum með endurtekna dettni. ${ }^{13,14}$

раð er rétt að taka fram að tækið getur greint takttruflanir sem ekki valda einkennum hjá sjúklingi. Klíníska pýðingu slíkra takttruflana verður að meta í hverju tilfelli fyrir sig. Ef um er að ræða til dæmis hraðtakt með gleiðum QRS-samstæðum eða gáttatif parf að taka afstöðu til meðferðar óháð pví hvort takttruflunin leiddi til einkenna eða ekki.

Í heild sýnir pessi könnun fram á gagnsemi af notkun ígræddra taktnema hjá sjúklingum með yfirlið sem eru oútskýrð prátt fyrir ítarlegar rannsóknir. Í framtíðinni mun notkun ígræddra taktnema undir fleiri klínískum kringumstæðum, svo sem til eftirlits með meðferð hjartsláttartruflana, trúlega fara vaxandi. 


\section{Heimildir}

1. Disertori M, Brignole M, Menozzi C, Raviele A, Rizzon $\mathrm{P}$, Santini M, et al. Management patients with syncope referred urgently to general hospitals. Europace 2003; 5: 283-91.

2. Blanc JJ, L’Her C, Touiza A, Garo B, L’Her E, Mansourati J. Prospective evaluation and outcome of patients admitted for syncope over a 1 year period. Eur Heart J 2002; 23: 81520.

3. Olshansky B, Poole JE, Johnson G, Anderson J, Hellkamp AS, Packer D, et al. Syncope predicts the outcome of cardiomyopathy patients: analysis of the SCD-HeFT study. J Am Coll Cardiol 2008; 51: 1277-82.

4. Pezawas T, Stix G, Kastner J, Wolzt M, Mayer C, Moertl D, et al. Unexplained syncope in patients with structural heart disease and no documented ventricular arrhythmias: value of electrophysiologically guided implantable cardioverter defibrillator therapy. Europace 2003; 5: 305-12.

5. Ammirati F, Colivicchi F, Santini M. Diagnosing syncope in clinical practice. Implementation of a simplified diagnostic algorithm in a multicentre prospective trial - the OESIL 2 study (Osservatorio Epidemiologico della Sincope nel Lazio). Eur Heart J 2000; 21: 935-40.

6. Sarasin FP, Louis-Simonet M, Carballo D, Slama S, Rajeswaran A, Metzger JT, et al. Prospective evaluation of patients with syncope: a population-based study. Am J Med 2001; 111: 177-84

7. Davis S, Westby M, Pitcher D, Petkar S. Implantable loop recorders are cost-effective when used to investigate transient loss of consciousness which is either suspected to be arrhythmic or remains unexplained. Europace 2012; 14: 402-9.

8. Krahn A, Klein GJ, Yee R, Takle-Newhouse T, Norris C. Use of an extended monitoring strategy in patients with problematic syncope. Reveal Investigators. Circulation 1999; 26: 406-10.

9. Moya A, Brignole M, Menozzi C, Garcia-Civera R, Tognarini S, Mont L, et al. Mechanism of syncope in patients with isolated syncope and tilt-positive syncope. Circulation 2001; 104: 1261-7.
10. Edvardsson N, Frykman $\mathrm{V}$, van Mechelen $\mathrm{R}$, Mitro P, Mohii-Oskarsson A, Pasquié JL, et al. Use of an implantable loop recorder to increase the diagnostic yield in unexplained syncope: results from the PICTURE registry. Europace 2011; 13: 262-9.

11. Moya A, Sutton R, Ammirati R, Blanc JJ, Brignole M, Dahm $\mathrm{JB}$, et al. Guidelines for the diagnosis and management of syncope (version 2009). Eur Heart J 2009; 30: 2631-71

12. Vitale E, Ungar A, Maggi R, Francese M, Lunati M, Colaceci R, et al. Discrepancy between clinical practice and standardized indications for an implantable loop recorder in patients with unexplained syncope. Europace 2010; 12 : 1475-9.

13. Zaidi A, Clough P, Cooper P, Scheepers B, Fitzpatrick AP. Misdiagnosis of epilepsy: many seizure-like attacks have a cardiovascular cause. J Am Coll Cardiol 2000; 36: 181-4.

14. Kenny RA, Richardson DA, Steen N, Bexton RS, Shaw FJ, Bond J. Carotid sinus syndrome: a modifiable risk factor for nonaccidental falls in older adults (SAFE PACE). J Am Coll Cardiol 2001; 38: 1491-6.

\section{ENGLISH SUMMARY}

\section{The usefullness of implantable loop recorders for evaluation of unexplained syncope and palpitations}

Kristjansdottir I, Reimarsdottir G, Arnar DO

Objective: Syncope is a common complaint and determining the underlying cause can be difficult despite extensive evaluation. The purpose of this study was to evaluate the usefulness of an implantable loop recorder for patients with unexplained syncope and palpitations. Material and methods: This was a retrospective analysis of 18 patients, five of whom still have the device implanted. All patients had undergone extensive evaluation for their symptoms before getting the loop recorder implanted and this was therefore a highly select group. Results: Of the thirteen patients where use of the device was completed, the mean age was $65 \pm 20$ years. The loop recorder was in use for a mean time of $20 \pm 13$ months. Unexplained syncope, eleven of thirteen, was the most common indication. The other two received the loop recorder for unexplained palpitations. Four patients had sick sinus syndrome during monitoring, three had supraventricular tachycardia and one had ventricular tachycardia. Further three had typical symptoms but no arrhythmia was recorded and excluding that as a cause. Two patients had no symptoms the entire time they had the loop recorder. Of the five patients still with the device three had syncope as the indication for monitoring and two have the device as a means of evaluating the results of treatment for arrhythmia.

Conclusion: This study on our initial experience with implantable loop recorders shows that these devices can be useful in the investigation of the causes of syncope and palpitations.

Key words: Syncope, palpitations, implantable loop recorder.

Correspondence: Davíð O. Arnar, davidar@landspitali.is

Landspitali - The National University Hospital of Iceland. 